\title{
The postcolonial moment in security studies
}

\author{
TARAK BARKAWI AND MARK LAFFEY*
}

A bstract. In this article, we critique the Eurocentric character of security studies as it has developed since World War II. The taken-for-granted historical geographies that underpin security studies systematically misrepresent the role of the global South in security relations and lead to a distorted view of Europe and the W est in world politics. U nderstanding security relations, past and present, requires acknowledging the mutual constitution of European and non-European worlds and their joint role in making history. The politics of Eurocentric security studies, those of the powerful, prevent adequate understanding of the nature or legitimacy of the armed resistance of the weak. Through analysis of the explanatory and political problems Eurocentrism generates, this article lays the groundwork for the development of a non-Eurocentric security studies.

Security relations today are about the contradictions between old security logics and new security problematics. Traditionally, security studies has been concerned with relations between and among great powers in the international system, itself understood as composed of stronger and weaker sovereign territorial states. The history of international relations is conceived primarily in terms of successive struggles between great powers and the rise and fall of powerful states. ${ }^{1}$ Questions of war and peace raised by great power competition are foundational for security thought and practice, and because of the primacy of security, for understanding world politics more broadly.

R ecent developments in world politics challenge these verities. In the contemporary era, W estern powers face an 'existential threat' from a transnational network enterprise rather than from states organised along similar lines as in the past. ${ }^{2}$ This development represents a break with putative histories of world politics as about great power struggles. Al-Qaeda is not a state nor a great power; it is a transnational network and more importantly an idea around which resistance is organised globally and locally. ${ }^{3}$ Thinking derived from conventional security

* For comments thanks to D uncan Bell, J ohn Game, G eoffrey H awthorne, Jane H ayward, Stephen Hopgood, Charles J ones, R ichard N ed L ebow, Daniel N exon, L ouiza Odysseos, G len R angwala, J ustin R osenberg, M artin Shaw, N aveed Sheikh and especially $\mathrm{N}$ aeem Inayatullah and J utta Weldes.

1 See, for example, R obert Gilpin, War and Change in World Politics (Cambridge: Cambridge U niversity Press, 1981); Paul K ennedy, The Rise and Fall of the Great Powers: Economic Change and Military Conflict from 1500-2000 (London: F ontana, 1989); J ohn M earsheimer, The Tragedy of Great Power Politics (N ew Y ork: W. W. Norton, 2003).

2 Condoleezza Rice, 'A balance of power that favors freedom', 10 ctober 2002, 〈http:// www.manhattaninstitute.org/html/w12002.htm), accessed 29 N ovember 2003. See also G raham Allison, Nuclear Terrorism: The Ultimate Preventable Catastrophe (N ew Y ork: Times Books, 2004).

3 A nonymous, Imperial Hubris: Why the West is Losing the War on Terror (Washington, DC: Brassey's, 2004); J ason Burke, Al-Qaeda: Casting a Shadow of Terror (London: I. B. Tauris, 2003). 
studies, then, is at best a poor basis for understanding and action in contemporary security environments. ${ }^{4}$

A major reason for this inadequacy is that security studies derives its core categories and assumptions about world politics from a particular understanding of E uropean experience. In this article, we critique the E urocentric character of security studies as it has developed since the Second World War. As we will show, the taken-for-granted historical geographies that underpin security studies systematically understate and misrepresent the role of what we now call the global South in security relations. ${ }^{5}$ Eurocentrism also leads to a distorted analysis of Europe and its place in world politics. Understanding security relations, past and present, requires acknowledging the mutual constitution of Europe and the non-E uropean world and their joint role in making history. In detailing the explanatory and political problems Eurocentrism generates, this article clears ground for the development of a nonEurocentric security studies.

R eframing security analysis in these terms helps make sense of contemporary developments by drawing attention to the implication of the 'War on Terror' in longer histories of warfare between the global North and the global South. ${ }^{6}$ For O sama bin Laden, 'The west's occupation of our countries is old, but takes new forms. The struggle between us and them began centuries ago, and will continue. ${ }^{7}$ The ability of a Southern resistance movement to inflict wounding strikes on the home territory of a leading metropolitan power is nearly unprecedented. N evertheless, armed conflict between North and South is very old. In conventional security studies, these conflicts are understood under the rubric of 'small wars' or asymmetric conflict and conceived as peripheral to, and derived from, the main action among great powers. ${ }^{8} \mathrm{~N}$ ow, what seemed peripheral has become central. The 'natives' have struck back, and are likely to continue doing so. This marks a significant moment of postcolonial rupture in the history of security relations. ${ }^{9}$ Previously, Southern resistance movements sought national liberation and the end of formal and informal colonial rule in their own states. The resistance movement taking shape around A I-Q aeda, and the reactions to it, are global in scope and not limited to particular states or even a particular region. For us, A I-Qaeda's spectacular intervention and ongoing role in contemporary world politics highlights the necessity of reformulating the categories we deploy to make sense of both past and present security relations.

${ }^{4}$ M ark Duffield, 'W ar as a network enterprise: the new security terrain and its implications', Cultural Values, 6:1\&2 (2002), pp. 153-165; R obert K eohane, 'The G lobalization of Informal Violence, Theories of W orld Politics, and "the Liberalism of F ear" ' in Craig Calhoun et al. (eds.), Understanding September 11 (N ew Y ork: The N ew Press, 2002), pp. 89-90.

${ }^{5} \mathrm{O}$ the role of spatial categories and metageographies such as $\mathrm{N}$ orth-South and East-W est in social inquiry, see M artin L ewis and K ärin Wigen, The Myth of Continents: A Critique of Metageography (Berkeley, CA : U niversity of California Press, 1997). On N orth-South in particular, see D avid Slater, Geopolitics and the Post-Colonial: Rethinking North-South Relations (Oxford: Blackwell, 2004), pp. 5-10, 228-30.

6 Derek Gregory, The Colonial Present: Afghanistan, Palestine, Iraq (Oxford: Blackwell, 2004), and M ahmood M amdani, Good Muslim, Bad Muslim: America, the Cold War and the Roots of Terror (N ew Y ork: Pantheon, 2004).

7 Osama bin Laden, 'R esist the N ew Rome', The Guardian, 6 J anuary 2004, p. 23.

8 Tarak Barkawi, 'On the Pedagogy of "Small Wars"', International Affairs, 80:1 (2004), pp. 19-38.

9 On Postcoloniality, see Slater, Geopolitics and the Post-Colonial, pp. 20-21; cf. A nne M cClintock, 'The A ngel of Progress: Pitfalls of the Term "Post-Colonialism"' ', Social Text, 31/32 (1992), pp. 84-98. 
The rootedness of the current conflict in centuries of often violent interaction between $\mathrm{N}$ orth and South is difficult to see due to security studies' reliance on histories and geographies which reproduce Eurocentric conceptions of world politics. This problem is not peculiar to security studies. A ccording to Barry Buzan and R ichard Little, 'there is no doubt that I[nternational] R [elations] has been studied from a very Eurocentric perspective ...'10 Eurocentrism is a complex idea but at its core is the assumption of European centrality in the human past and present. ${ }^{11}$ On this view, Europe is conceived as separate and distinct from the rest of the world, as self-contained and self-generating. A nalysis of the past, present and future of world politics is carried out in terms - conceptual and empirical, political and normative - that take for granted this centrality and separation. ${ }^{12}$ $\mathrm{N}$ either the content - social, political, economic and cultural - nor the geographical location of 'Europe' are fixed. Eurocentrism is about both a real and an imagined Europe. Over time, as M artin L ewis and $K$ ären Wigen demonstrate, the location of Europe shifts, expands and contracts, eventually crossing the A tlantic and the Pacific and becoming synonymous with the 'W est'.13 Today, the 'W est' is centred on the Anglophone US - a former European settler colony - and incorporates Western Europe, North America, Japan and the British settler societies of Oceania. There are few better examples of Eurocentrism than the notion that the end-point of development and modernisation is defined by the contemporary W est.

The E urocentrism of conventional security studies takes different forms across the theoretic perspectives that constitute the field. For realists, a 'general theory of international politics is necessarily based on the great powers'. ${ }^{14}$ In modern history those powers are overwhelmingly located in Europe and the West. Eurocentrism is therefore intrinsic to the way in which realism is constructed in International R elations (IR ). ${ }^{15}$ The great antagonists of realism, the liberals, seek to regulate conflict and alleviate its humanitarian consequences through a turn to domestic and international institutions and norms. International institutions such as the L eague of $\mathrm{N}$ ations, the $\mathrm{U}$ nited $\mathrm{N}$ ations and the nuclear non-proliferation regime are largely the product of interstate diplomacy dominated by Western great powers. ${ }^{16} \mathrm{M}$ oreover, liberal democracy and the ethical principles that inform liberal opinion are the product of purportedly European histories and intellectual trajectories, most prominently those associated with the Enlightenments. ${ }^{17} \mathrm{M}$ any constructivists share

10 Barry Buzan and Richard Little, International Systems in World History: Remaking the Study of International Relations (Oxford: Oxford U niversity Press, 2000), p. 21. See, for example, Sankaran K rishna, 'R ace, A mnesia and the Education of International R elations', Alternatives, $26: 4$ (2001), pp. 401-24; A rlene Tickner, 'Seeing IR D ifferently: $N$ otes from the Third W orld', Millennium, 32:2 (2003), pp. 295-324.

11 See, for example, Samir A min, Eurocentrism (N ew Y ork: M onthly R eview Press, 1989); F ernando Coronil, 'Beyond Occidentalism: Toward N onimperial Geohistorical Categories', Cultural Anthropology, 11:1 (1996), pp. 51-87.

12 Dipesh Chakrabarty, Provincializing Europe: Postcolonial Thought and Historical Difference (Princeton, N J: Princeton U niversity Press, 2000); John Hobson, The Eastern Origins of Western Civilisation (Cambridge: Cambridge U niversity Press, 2004), ch. 1.

13 L ewis and Wigen, Myth of Continents, pp. 49-53.

14 K enneth Waltz, Theory of International Politics (N ew Y ork: M cG raw-H ill, 1979), p. 73.

15 For an important corrective, see Buzan and Little, International Systems in World History. On the E urocentric nature of realist political theoretic categories, see R. B. J. Walker, 'R ealism, change and international political theory,' International Studies Quarterly, 31:1 (1987), pp. 65-86.

16 See, for example, Peter Gowan, 'U S:U N', New Left Review, 24 (2003), pp. 5-28.

17 R ecent scholarship argues there was not one but several Enlightenments. See, for example, J. G. A. Pocock, Barbarism and Religion, vols 1-3 (Cambridge: Cambridge U niversity Press, 1999-2003). 
similar commitments as in attempts to make sense of international order in Hobbesian, Lockean or Kantian terms. ${ }^{18}$ R ecent efforts to move beyond the realist-liberal debate, such as Critical Security Studies, draw their core concept of human emancipation from these same intellectual traditions. ${ }^{19}$ Each of these traditions, as postcolonial thinkers take pains to point out, rest on profoundly Eurocentric and racist assumptions. ${ }^{20}$ As Immanuel $\mathrm{K}$ ant, a figure dear to both liberal and critical scholars, observed, 'H umanity achieves its greatest perfection with the White race'. ${ }^{21}$

Eurocentrism generates a variety of difficulties for the analysis of security relations, and world politics more generally. ${ }^{22}$ Two in particular motivate our argument here. First, as we have noted, questions of war and peace raised by great power competition are foundational for security thought and practice. A s a result, security studies provides few categories for making sense of the historical experiences of the weak and the powerless who comprise most of the world's population. By default, these experiences are conceived in categories derived from great power politics in the $\mathrm{N}$ orth. Consequently, national liberation struggles in the post-World W ar II era were thought of in Cold W ar terms by many U S policymakers and defence intellectuals. ${ }^{23}$ Today, this categorical error is repeated in a new form. Armed resistance to $\mathrm{N}$ orthern domination of the international system is subsumed largely under the category of 'terrorism'. In contemporary usage this term legitimates state power and delegitimates the use of force by non-state actors. ${ }^{24}$ It assumes in advance that 'terrorist' acts are always illegitimate and unjustified. Understanding why the weak resist and the forms their resistance takes is not aided by calling them names.

Second, and related, to the extent it addresses them at all, a Eurocentric security studies regards the weak and the powerless as marginal or derivative elements of world politics, as at best the site of liberal good intentions or at worst a potential source of threats. ${ }^{25} \mathrm{M}$ issed are the multiple and integral relations between the weak and the strong. A cross diverse fields of social inquiry, it is taken for granted that the weak and the strong must be placed in a common analytic frame, as together constitutive of events, processes and structures. ${ }^{26}$ In contrast IR, and security studies

18 A lexander Wendt, Social Theory of International Politics (Cambridge: Cambridge U niversity Press, 1999).

19 K en Booth (ed.), Critical Security Studies and World Politics (Boulder, CO: L ynne R ienner, 2005).

20 U day Singh M ehta, Liberalism and Empire: A Study in Nineteenth Century British Liberal Thought (Chicago, IL: U niversity of Chicago Press, 1999); N aeem Inayatullah and D avid Blaney, International Relations and the Problem of Difference (L ondon: R outledge, 2004).

21 Immanuel K ant, Geographie (Physiche Geographie), trans. M. Cohen-Halmimi et al. (Paris: Bibliotheque Philosophique, 1999); quoted in David Harvey, 'Cosmopolitanism and the Banality of G eographical Evils', Public Culture, 12:2 (2000), p. 533. Cf. Sankar M uthu, Enlightenment against Empire (Princeton, N J : Princeton U niversity Press, 2003).

22 M ohammed A yoob, The Third World Security Predicament: Statemaking, Regional Conflict and the International System (Boulder, CO: L ynne R ienner, 1995); cf. Sankaran K rishna, Postcolonial Insecurities: India, Sri Lanka and the Question of Nationhood (M inneapolis, M N : U niversity of M innesota Press, 1999).

23 Gabriel K olko, Confronting the Third World: United States Foreign Policy 1945-1980 (N ew Y ork: Pantheon, 1988).

24 A lexander G eorge (ed.), Western State Terrorism (N ew Y ork: R outledge, 1991).

25 F or examples, see respectively M ary K aldor, New and Old Wars: Organized Violence in a Global Era, 2nd edn. (Cambridge: Polity, 2001) and Steven R. D avid, 'W hy the Third World Still M atters', International Security, 17:3 (1992/93), pp. 127-59.

26 See, for example, Barrington M oore, Social Origins of Dictatorship and Democracy: Lord and Peasant in the Making of the Modern World (Boston, M A : Beacon Press, 1993); Eric Wolf, Europe and the 
in particular, mainly proceed by attending to the powerful only. As Stanley $\mathrm{H}$ offmann notes, IR takes an 'A thenian' perspective on the world. ${ }^{27} \mathrm{~F}$ or realism, with its focus on great powers, one-sided analysis of this kind is foundational. F or liberal and some critical approaches to security studies, the weak are of interest but primarily as bearers of rights and objects of emancipation, that is, for their normative value in W estern political theoretic terms. ${ }^{28} \mathrm{~F}$ ailing to study the weak and the strong together, as jointly responsible for making history, hamstrings IR and security studies' ability to make sense of world politics generally and N orth-South relations in particular.

That the weak play an integral role in shaping world politics is harder to deny when a Southern resistance movement strikes at the heart of N orthern power. In the wake of those attacks, a series of developments transformed international and domestic politics around the world in diverse ways. Wars are being fought; alliance relations reconfigured; security forces redeployed; borders reworked; civil liberties curtailed; departments of state created; and identities remade. Understanding security relations now requires that we discard Eurocentric assumptions about the world and how it works.

In the next section, through analysis of several moments in the evolution of the field, we show that conventional security studies rests on and reproduces E urocentric histories and geographies of world politics. The second section addresses the problems for social scientific inquiry posed by Eurocentrism and begins to map out an alternative basis for security studies. In the third, we critique the politics of Eurocentric security studies. A brief conclusion identifies the character and wider implications of our argument.

\section{Security studies and E urocentrism}

E specially in the last decade or so, security studies has become a vibrant and diverse field of inquiry. ${ }^{29}$ Despite this diversity, as with any well-developed body of disciplinary knowledge, debates take place on ground that, if not entirely common, is at least recognisable amongst competing perspectives. Security studies in its modern form emerges in the wake of World W ar II and was originally organised around the familiar realist problematic of great powers and their relations. ${ }^{30} \mathrm{M}$ uch of the debate in security studies, then and now, is concerned with either elaborating this problematic or challenging it. F amiliar historical episodes and new ones, such as the Concert of Europe, the origins of World War I, the appeasement of $\mathrm{Nazi}$

People Without History (Berkeley, CA : U niversity of California Press, 1997); C. A. Bayly, The Birth of the Modern World, 1780-1914: Global Connections and Comparisons (Oxford: Blackwell, 2004).

27 Stanley H offmann, 'A n A merican Social Science: International R elations', Daedalus, 106:3 (1977), p. 58.

28 See, for example, Tim D unne and N icholas Wheeler (eds.), Human Rights in Global Politics (Cambridge: Cambridge U niversity Press, 1999); K en Booth, 'Security and Emancipation', Review of International Studies, 17:3 (1991), pp. 313-26.

29 See, for example, R onnie Lipschutz (ed.), On Security (N ew Y ork: Columbia U niversity Press, 1995); Peter K atzenstein (ed.), The Culture of National Security: Norms and Identity in World Politics (N ew Y ork: Columbia U niversity Press, 1996); Barry Buzan and Ole W aever, Regions and Powers: The Structure of International Security (Cambridge: Cambridge U niversity Press, 2003).

30 J ohn Vasquez, The Power of Power Politics: From Classical Realism to Neotraditionalism (Cambridge: Cambridge U niversity Press, 1999). 
G ermany, and the end of the Cold W ar are analysed, interpreted and reinterpreted. ${ }^{31}$ Divisions and disagreements over the meaning of these episodes aside, the competing paradigms and divergent political persuasions that characterise contemporary security studies occupy a shared Eurocentric historical and geographic terrain. ${ }^{32}$

Security studies after 1945 is defined largely by heated disputes between realist and liberal positions, broadly conceived. L ater, the constructivists joined the fray. ${ }^{33}$ These disputes presuppose and reproduce, separately and together, a specific set of historical periodisations and spatial assumptions. By historical periodisations we mean the taken-for-granted chronologies of key actors, central processes and significant events that structure the field. By spatial assumptions, we mean the frameworks that organise the world in spatial terms and locate these actors, processes, and events, both in relation to each other and to world politics more generally. Taken together, these temporal and spatial assumptions produce Eurocentric historical geographies. ${ }^{34}$ In turn, a security studies rooted in this ground inevitably expresses a particular politics, in terms of those actors and concerns that are seen as most important. The Anglo-American character of IR is wellestablished. ${ }^{35} \mathrm{U}$ nsurprisingly, conventional security studies, the core of IR, is also shaped by the politics of a particular time and place - the post-1945 A nglo-A merican world - even as it presents itself in the seemingly neutral and timeless language of social science. ${ }^{36}$

Eurocentric historical geographies and periodisations are very much in evidence in the common narratives of world history that underpin security studies. F or example, the wars of R evolutionary and $\mathrm{N}$ apoleonic $\mathrm{F}$ rance give way to the nineteenth century Concert of Europe, which in turn leads to the half-century conflict to prevent G erman hegemony. The period after 1945 is seen as one of 'E ast-W est' struggle, that is, between competing coalitions organised around the U S and the U SSR. In terms of spatial assumptions, what is most evident about these very conventional and widely accepted periodisations is that world politics is taken to be happening almost exclusively in Europe, or latterly in the N orthern hemisphere. ${ }^{37}$ To the extent that world politics is seen as taking place elsewhere, as in the Third World during the

31 See, for example, R ichard N ed Lebow and Thomas R isse-K appen (eds.), International Relations Theory and the End of the Cold War (N ew Y ork: Columbia U niversity Press, 1995); G lenn Snyder, Alliance Politics (Ithaca, N Y : Cornell U niversity Press, 1997); Stephen Van Evera, Causes of War: Power and the Roots of Conflict (I thaca, NY: Cornell U niversity Press, 1999).

32 Even a 'post-positivist' critique of security studies has no index entries for imperialism, colonialism, or postcolonialism. See Terry Terriff et al., Security Studies Today (Cambridge: Polity, 1999).

33 K atzenstein, Culture of National Security; cf. J utta W eldes et al. (eds.), Cultures of Insecurity: States, Communities and the Production of Danger (M inneapolis, M N : U niversity of M innesota Press, 1999).

34 On the spatial turn in social theory, see Edward Soja, Postmodern Geographies: The Reassertion of Space in Critical Social Theory (L ondon: Verso, 1989). On historical geography, see J ohn A gnew and Stuart Corbridge, Mastering Space: Hegemony, Territory and International Political Economy (N ew Y ork: R outledge, 1995); A rjun A ppadurai, Modernity at Large (M inneapolis, M N : U niversity of M innesota Press); D erek Gregory, Geographical Imaginations (Oxford: Blackwell, 1993); and D avid Harvey, Spaces of Capital: Towards a Critical Geography (N ew Y ork: R outledge, 2001).

35 H offmann, 'A n A merican Social Science'; Steve Smith, 'The D iscipline of International R elations: Still an A merican Social Science?' British Journal of Politics and International Relations, 2:3 (2000), pp. 374-402.

36 Compare Ido Oren, Our Enemies and Us: America's Rivalries and the Making of Political Science (Ithaca, NY: C ornell U niversity Press, 2003).

37 Cf. Sankaran K rishna, 'R ace, A mnesia, and the Education of International R elations', pp. 404-6. 
Cold War, it is derivative of European developments and driven by great-power competition and the diffusion of European ideas and institutions. ${ }^{38}$

Below, through analysis of a set of key moments in the evolution of security studies as a field, we begin to map the shared terrain on which debates take place. Specifically, we examine the historical geography of world politics as expressed in a conventional account of the genealogy of war and strategy, the Cuban missile crisis, World War II and the Holocaust and show it to be deeply Eurocentric. These moments represent, respectively and together, important dimensions of E urocentrism in security studies: the Orientalism expressed in and structuring key texts; the assumption of great-power agency in empirical inquiry; the often unacknowledged A nglo-A merican politics shaping the definition of key events; and the presumed ethical character of the W est. Our discussion should be interpreted symptomatically, that is, as identifying some of the exclusions and hidden infrastructure that make possible security studies. ${ }^{39}$

\section{M akers of M odern Strategy and the 'national-political approach'}

A $n$ initial sense of the ways in which E urocentric histories and geographies shape and inform the field of security studies can be gleaned from the tables of contents of canonical texts, such as the two main editions of Makers of Modern Strategy. ${ }^{40}$ The first was the result of a seminar at Princeton U niversity in 1941 organised by E dward $M$ ead Earle. This edition, a modern classic, was a standard in the field until it was substantially revised and expanded in 1986 by Peter Paret. For Earle, modern war emerges and is theorised as a distinctively European experience beginning in the sixteenth century. All of the chapters except two concern either European wars or W estern theorists of war. A s J eremy B lack observes, military history 'concentrates on W estern history and is very much Euro-centred even when it considers developments elsewhere in the world'. ${ }^{41}$

A ccordingly, of the two exceptions, one chapter concerns J apanese naval strategy, obviously a pressing matter for A merican strategic thinkers in 1941. The other discusses the development of $F$ rench colonial warfare from the perspective of $F$ rance as an imperial power. F rom this perspective, colonial war 'aims not at the destruction of the enemy but at the organization of the conquered peoples and territory under a particular control ... . because the conquered country is to be integrated immediately after the conquest into the "imperial" whole, politically as well as economically.' The point of colonial warfare, then, is not simply to defeat the enemy but 'to subordinate him at the lowest cost and in a way to guarantee permanent pacification'. 42

\footnotetext{
38 See, for example, R obert J ackson, 'The W eight of I deas in D ecolonization: N ormative Change in International R elations', in J udith Goldstein and Robert K eohane (eds.), Ideas and Foreign Policy: Beliefs, Institutions and Political Change (Ithaca, NY : Cornell U niversity Press, 1993), pp. 111-138.

39 On symptomatic reading, see, for example, R obert Paul R esch, Althusser and the Renewal of Marxist Social Theory (Berkeley, CA : U niversity of California Press, 1992), pp. 174-8.

40 Edward M ead Earle (ed.), Makers of Modern Strategy: Military Thought from Machiavelli to Hitler (Princeton, N J : Princeton U niversity Press, 1948 [1943]); Peter Paret (ed.), Makers of Modern Strategy: From Machiavelli to the Nuclear Age (Oxford: Clarendon Press, 1986).

41 Jeremy Black, War and the World: Military Power and the Fate of Continents, 1450-2000 (N ew H aven, CT: Y ale U niversity Press, 1998), p. 1.

42 J ean G ottmann, 'Bugeaud, G alliéni, L yautey: The D evelopment of F rench Colonial Warfare', in Earle, Makers of Modern Strategy, pp. 234-5.
} 
Taking an imperial perspective on war in the colonies highlights the politically interested character of security studies. The entire text takes for granted and expresses the point of view of Western great powers in a world they dominate and compete over. Peter Paret claimed in his 1986 introduction that the 'wartime origin and mission' of Earle's volume 'did not compromise its scholarly objectivity' - none of the chapters was 'marred by chauvinism' - specifically mentioning in this context the chapter on Japanese naval strategy. ${ }^{43}$ That chapter begins, however, with the observation that ' $F$ rom a military standpoint the J apanese mind may be described as being subjective rather than objective'. 44

Whereas an American or a British analyst has no difficulty discussing naval strategy in an abstract and disinterested manner, a J apanese has 'difficulty eliminating the national-political approach'. ${ }^{4}$ In a standard Orientalist manoeuvre, rationality and objectivity are attributed to the Anglo-A mericans, while the Japanese remain bogged down in parochial concerns. In M ead's introduction, he makes clear his volume is intended to teach 'A nglo-Saxon' readers about the nature of war so they may defend their liberty, and to inform A merican policymakers about how to use their 'great power', which will be 'momentous for ourselves and for the world'. ${ }^{46}$ This too, it seems to us, is a 'national-political approach', consistent with the A nglo-A merican character of the field. As E dward L uttwak remarks, 'strategy is not a neutral pursuit and its only purpose is to strengthen one's side in the contention of nations'.47 The 1986 edition retains substantially the same coverage of Western military theorists and European military history, while adding concerns that had arisen since the end of W orld W ar II such as Soviet strategy and nuclear weapons. One significant addition is John Shy and Thomas Collier's fine discussion of revolutionary war. ${ }^{48}$ That revolutionary war, particularly in the Third World, had by 1986 become a major issue for W estern policymakers, goes without saying.

\section{The Cuban Missile Crisis and the location of agency}

One place where revolutionary war became a concern was Cuba, the site of a paradigmatic moment in the evolution of security studies. The Cuban M issile Crisis is central to debates concerning, among other things, the nature of deterrence, rational decision-making and the Cold War itself. Indeed, as an object of analysis, crisis management emerges out of scholarly and policy efforts to come to terms with the Cuban M issile Crisis. In standard accounts, the crisis is an affair of the superpowers only: 'F or thirteen days in October 1962, the U nited States and the Soviet U nion stood "eyeball to eyeball", each with the power of mutual annihilation in hand'. ${ }^{49}$ Cuba is conceived either as a client state of the Soviet U nion, whose

\footnotetext{
43 Paret, Makers of Modern Strategy, p. 5.

44 A lexander K iralfy, 'J apanese N aval Strategy,' in Earle, Makers of Modern Strategy, p. 459.

45 K iralfy, 'J apanese N aval Strategy', p. 459.

46 Edward Earle M ead, 'Introduction', in Makers of Modern Strategy, p. viii.

47 Quoted in Philip K. Lawrence, 'Strategy, the State and the Weberian L egacy', Review of International Studies, 13 (1987), p. 307.

48 J ohn Shy and Thomas Collier, 'R evolutionary War', in Paret, Makers of Modern Strategy.

49 Graham Allison, Essence of Decision: Explaining the Cuban Missile Crisis (Boston: Little Brown, 1971), p. 39.
} 
actions are an extension of Soviet policy, or as simply the location of a dispute between the US and the USSR. A s J utta W eldes comments, both in the ExComm discussions and most subsequent scholarship, 'Cuba appeared . . . merely as a place, and a "little pipsqueak of a place" at that'.50

A basic difficulty with this E urocentric construction is that in writing Cuba out of the Cuban M issile Crisis, important dynamics and variables were overlooked by policymakers at the time and by most subsequent scholarship. U S officials meeting in the ExComm failed to recognise the role of their own past policies towards Cuba in generating the crisis. D espite U S perceptions of Soviet allies in the Third W orld as mere puppets, nuclear missiles could never have been placed in Cuba without Cuban agreement. ${ }^{51}$ Castro, realistically fearful of another invasion after the Bay of Pigs, turned to the Soviet U nion for help in defending Cuban sovereignty and the Cuban revolution. Without these Cuban motivations, it is unlikely there would have been a crisis; the missiles were placed onto Cuban territory in part to defend it. Overlooking Cuban agency prevented participants and scholars from realising, until quite recently, that Castro also played a significant role in the actual crisis. When Fyodor Burlatsky, one of K hrushchev's advisors, was asked by Theodore Sorensen in 1989 'what outside influences were brought to bear on the K remlin's decision making' during the crisis, he responded, 'the first influence was from Castro'. 52

The failure to recognise the Cuban role in the crisis, both at the time and subsequently, reproduces the Eurocentric assumption that agency - real, historically significant agency - only resides in the great powers. Even well-resourced scholarship of the highest quality took several decades to begin to uncover the significance of the Cubans in their own crisis. This explains why, in 1993, Bruce A llyn, James Blight and $D$ avid Welch found it necessary to argue that 'The Cuban missile crisis was very much a Cuban affair'. ${ }^{53}$ In the late 1980 s a series of scholarly meetings were set up to bring together the key participants in the crisis. ${ }^{54}$ It was not until the third such meeting, held in M oscow in January 1989, that Cuban representatives were even invited, and then only at Soviet insistence. A merican representatives resisted Cuban participation on the grounds that this would turn the meeting into a 'political circus'. ${ }^{55}$ Like Japanese naval strategists, it was assumed that Cubans would be incapable of stepping outside a 'national-political approach'. At this meeting, and a subsequent one attended by Castro in Havana in January 1992, evidence of the Cuban role, some of which we mention above, began to emerge. The crisis, for

50 Jutta Weldes, Constructing National Interests: The United States and the Cuban Missile Crisis (M inneapolis, M N : U niversity of M innesota Press, 1999), p. 75, quoting U SM C Commandant D avid Shoup.

51 Weldes, Constructing National Interests, pp. 80-3.

52 James Blight and David Welch, On the Brink: Americans and Soviets Reexamine the Cuban Missile Crisis, 2nd edn. (N ew Y ork: N oonday Press, 1990), p. 266.

53 J ames Blight, David Welch and Bruce Allyn, Cuba on the Brink: Castro, the Missile Crisis and the Soviet Collapse (N ew Y ork: Pantheon, 1993), p. 5. See also Scott A rmstrong and Philip Brenner, 'Putting Cuba and Crisis Back in the Cuban M issile Crisis,' in Philip Brenner, William M . L eoG rande, D onna Rich, and Daniel Siegel (eds.), The Cuba Reader: The Making of a Revolutionary Society (N ew Y ork: G rove Press, 1989), pp. 336-9.

54 R eports and transcripts of the meetings are contained in Blight and Welch, On the Brink; Allyn, Blight and Welch (eds.), Back to the Brink: Proceedings of the Moscow Conference on the Cuban Missile Crisis, 27-28 January 1989 (Lanham, M D : U niversity Press of A merica, 1992); and Blight, Welch and Allyn, Cuba on the Brink.

55 D avid W elch, quoted in J utta W eldes and M ark L affey, 'D ecolonizing the Cuban M issile Crisis', unpublished ms., p. 20. 
example, could not end until Castro permitted the missiles to be removed, in exchange for a Soviet brigade to defend Cuba. ${ }^{56}$

Even so, US scholars still had difficulty granting the possibility of objectivity to Cuban policymakers and scholars. The editors of Back to the Brink state that whereas the A mericans and the Soviets ' came mainly to give and hear testimony regarding the story of the crisis ... for the Cubans ... the more they learned and shared, the more profoundly embedded they inevitably became in the overriding issues of their present situation: their highly abnormal relations with their near neighbour and their far away ally'.57 This depiction of politicised Cubans and apolitical A mericans (and Soviets) is unsustainable. Narrowly construed, as the study of rational crisis decision-making, U S scholarly interest in the Cuban M issile Crisis also betrays a 'national-political approach', one that takes U S concerns for granted. The claim to rational decision-making is frequently used by great powers to justify the possession of nuclear weapons. Conversely, the purported lack of rationality on the part of other states, particularly revolutionary regimes like Cuba or I ran, is routinely invoked to explain why they cannot be trusted with nuclear weapons.58 Scholarly attention to 'rational decision making' - learning the lessons of the Cuban M issile Crisis - serves to reproduce this demonstrably Orientalist characterisation. In any case, 'abnormality' arises not only from the actions of Cuba. The US has maintained economic and other sanctions against Cuba long after the expiry of the Cold War strategic context. Cuba is a live issue in US politics, particularly in Florida, home to a large and well-organised expatriate Cuban community and a key battleground in US presidential elections. These facts of US policy and politics show that the causes and significance of the 'highly abnormal relations' between Cuba and the US are not confined to Cuba alone. Indeed, locating 'abnormality' on Cuba effectively obscures the long history of US imperialism in Cuba and the Caribbean.

\section{World War II: one or many?}

Even more significant for security studies than the Cuban $M$ issile Crisis are the various tropes, debates, lessons and theories derived from the origins, course and aftermath of the Second World War. The discipline of International Relations remains profoundly marked by its engagement with that conflict. The core debate between realists and liberals regarding the amelioration of great power conflict realpolitik versus international institutions - takes shape and rests upon competing accounts of the origins and aftermath of W orld War II. ${ }^{59}$ In turn, these discussions led to the development of a set of claims regarding the relative war-proneness of different regime types, subsequently formalised in the democratic peace debates.

Perhaps more important for the field of security studies is the shared standard interpretation of W orld W ar II as the 'good war'. A cross otherwise starkly divergent

56 Blight and Welch, On the Brink, pp. 266-7.

57 Allyn, Blight, and Welch, Back to the Brink, p. 202.

58 Hugh G usterson, People of the Bomb: Portraits of America's Nuclear Complex (M inneapolis, M N : U niversity of M innesota Press, 2004), ch. 2.

59 See, for example, E. H. Carr, The Twenty Years' Crisis 1919-1939 (London: M acmillan, 1946); David M itrany, A Working Peace System (Chicago, IL: Quadrangle Books, 1966). 
points of view, the war is seen as a struggle between democracy and totalitarianism, freedom and tyranny, good and evil, in which the 'good guys' won. Despite the decisive significance of the Soviet contribution to victory, the taken-for-granted view in the Anglo-A merican world is that the war was won by the US and its Western allies. ${ }^{60}$ This victory enabled and justified U S leadership of the postwar world and the centrality of the US and its concerns in security studies. U S 'victory' in World W ar II also confirmed a shift in the West's centre of gravity from Europe to North A merica.

For many in the colonised world, the meaning and significance of that conflict appeared starkly different. From these points of view, World War II was an inter-imperial war. ${ }^{61} \mathrm{~A}$ lthough the third point of the $\mathrm{A}$ tlantic $\mathrm{C}$ harter emphasised the rights of all peoples to self-government, W inston Churchill interpreted this pledge as applying only to peoples living under $\mathrm{N}$ azi occupation. ${ }^{62} \mathrm{~A}$ s a consequence, Indian nationalists, for example, were understandably sceptical of the A llies' purported war aims. They were afraid, as after W orld War I, that self-government was intended only for Europeans. A s one scholar of the mass uprising against B ritish rule that began in A ugust of 1942, known as 'Q uit I ndia', puts the point, 'I n spite of professing different ideological shibboleths, both the blocs [i.e., the Allies and the A xis] were essentially imperialist and colonialist in character. It was mainly for imperialist gains - either for acquiring them or for preserving them - that they got involved in this world-wide conflagration'.63

Such sentiments - equating the Allies with the A xis, the good guys with the bad guys - perhaps sound morally confused to some Western ears. ${ }^{64}$ But the war in the $\mathrm{F}$ ar East was in no small measure fought between Japan, the US, and Britain for control over China and Southeast A sia. It was for this reason that opposition to Japanese imperialism amongst Indian nationalists and others did not translate automatically into support for the British. While India did achieve independence after World War II - primarily because Britain realised it could no longer hold the sub-continent militarily - the larger point is that victory for the allies in both World $W$ ars meant freedom for some but not for others, and on terms defined by the victors. In Southeast A sia, the aftermath of World War II saw the reimposition or the attempted reimposition - sometimes with US support - of D utch, B ritish and F rench colonial rule, with catastrophic results in V ietnam. In other territories, where the US operated more independently, it developed forms of indirect rule and patron-client relations. In South K orea, for example, it established a regime based on those who had collaborated with the Japanese. ${ }^{65}$ It was this set of diverse and recognisably

60 Cf. Richard Overy, Why the Allies Won (N ew Y ork: N orton, 1995).

${ }^{61}$ Contemporaries on the European left also saw the war in these terms. See, for example, Ernest M andel, The Meaning of the Second World War (L ondon: Verso, 1986), pp. 45-6.

62 Christoper Thorne, Allies of a Kind: The United States, Britain and the War Against Japan, 1941-1945 (Oxford: Oxford U niversity Press, 1978), p. 102.

63 A run Chandra Bhuyan, The Quit India Movement: The Second World War and Indian Nationalism (N ew Delhi: M anas, 1975), p. 1.

64 But not all: 'We do not choose sides between imperialists ...' Ernest M andel, Revolutionary Marxism Today (London: N LB, 1979), p. 168. A lbert Camus, who like M andel participated in the resistance to $\mathrm{N}$ azi occupation, was more charitable to the W est, observing that " "We were fighting a lie in the name of a half-truth"' '. A Ibert Camus, Resistance, Rebellion, and Death (N ew Y ork: A Ifred K nopf, 1961), p. 248, quoting R ichard Hilary.

65 Bruce Cumings, Origins of the Korean War, Volume 1: Liberation and the Emergence of Separate Regimes, 1945-1947 (Princeton, N J Princeton U niversity Press, 1981), ch. 5. 
imperial arrangements that in part constituted the 'free world'. The selfdetermination the US offered was conditional, both in Western Europe and in the non-E uropean world, shaped amongst other things by Orientalist and racist assumptions about the relative capacity of different peoples for self-government. ${ }^{6} 6$

These points demonstrate the politically interested character of the standard historical geography of World War II as a 'good war' and its role in shaping the field of security studies. The Second W orld War is multi-vocal, subject to diverse and competing interpretations, depending on social and political location. Even the standard periodisation of 1939-1945 is a peculiarly Anglo-Saxon one. For the $J$ apanese and the Chinese, the Italians and the Ethiopians, the Czechoslovaks and the A ustrians, the war started some years earlier. ' $F$ or most Chinese ...', for example, 'the Second W orld War has been above all the A nti-J apanese R esistance War, whose beginnings by no means coincided with the start of the world war as viewed from Europe or the U nited States, and whose ending cannot be precisely dated at $1945^{\prime} .{ }^{67} \mathrm{~F}$ or Indonesians, Vietnamese, and Koreans, as for U krainians, $Y$ ugoslavs and $G$ reeks, the war carried on for some years after 1945. There is not one World War II - in the sense of a single authoritative interpretation - but many, fought over different times and spaces.

In a similar manner, R ussian and Cuban accounts of the 'Cuban M issile Crisis', which refer to the Caribbean and the $O$ ctober crisis respectively, rest on chronologies and spatial frames very different to the ' 13 days' of U S mythology. ${ }^{68} \mathrm{~F}$ or those who lived in N azi-occupied Western Europe, 1945 did mark a moment of freedom and liberation, albeit within terms defined by the US; those in Eastern Europe had to wait until 1989 to join the free world, and then on even less advantageous terms. 69 W orld War II represents something quite different for them, as it does for the much greater portion of the world's population living in the global South. $\mathrm{N}$ aturally, for these peoples, the meaning and political significance of W orld W ar II, like the Cuban M issile Crisis, is not easily encompassed in the standard Eurocentric readings.

\section{The Holocaust and the character of the West}

W orld War II is significant for security studies, and in particular liberal and critical approaches, in another way as well. Realist approaches to security studies are Eurocentric in that they locate agency and history with the great powers. Liberal approaches partake of this kind of Eurocentrism as well, but in addition they define the W est in ethical and progressive terms. The Holocaust is central to these efforts. A cross a range of positions, the $\mathrm{H}$ olocaust sets the standard for what is considered unacceptable behaviour in international society and invokes the category of 'humanity' in a Eurocentric fashion by ignoring previous W estern imperial genocides

66 M ichael H unt, Ideology and US Foreign Policy (N ew Haven, CT: Y ale U niversity Press, 1987).

67 T. F ujitani, G eoffrey W hite and L isa Y oneyama, 'Introduction', in F ujitani et al. (eds.), Perilous Memories: The Asia-Pacific War(s) (D urham, N C: D uke U niversity Press, 2001), p. 3.

68 W eldes, Constructing National Interests, pp. 22-37.

69 Peter Gowan, The Global Gamble: Washington's Faustian Bid for World Dominance (L ondon: Verso, 1999), ch. 9. 
in the colonies. ${ }^{70}$ Simultaneously, it reinforces narratives of the 'good war' as central to the self-fashioning of the W est as a collective actor in world politics. A fter all, it was the Allies who liberated the camps and prosecuted those responsible for the genocide. The turn to humanitarian intervention as a defining feature of a liberal, law-governed, and civilised 'international community', particularly since 1989, draws on and reinforces this image of the West as the preventer of genocides and the punisher of violators of human rights, as for example in K osovo.

Zygmunt Bauman argues, however, that the Holocaust is a modern, W estern phenomenon. ${ }^{71} \mathrm{~T}$ he $\mathrm{H}$ olocaust thus poses difficulties for liberal understandings of the W est and its role in world politics. 'W hoever takes seriously the history of violence in the twentieth century will find it hard to believe in myths of progress'. ${ }^{72}$ In order to retain liberal faith in W estern myths of progress and ethical superiority, in which the W est and humanity are collapsed into one another but the W est nevertheless also leads humanity, the H olocaust must be 'othered' from the W est. In defining the W est against the $\mathrm{H}$ olocaust, an imagined geography is invoked which displaces 'the sins of Western civilisation onto an intrusive non-European Other in our midst'. ${ }^{73}$ In the process, Germany, that quintessentially Western society, somehow becomes not W estern. ${ }^{74} \mathrm{~A}$ s L ewis and W igan comment, 'By the mid-twentieth century, historians across Europe were echoing the refrain that Germany was - in its "soul" - a non-Western country'.75 It is in this context that we should read the otherwise incomprehensible remark of Chancellor Gerhard Schröder that Germany has recently completed its 'long journey to the W est.' 76 This manoeuvre, othering mass slaughter from the W est and from modernity, is a standard one. It serves to preserve, in the face of any evidence to the contrary, the ethical character of the W est and, in turn, underpins claims in liberal and critical security studies that the West is a force for good in the world.

F or example, one site of mass slaughter was the Soviet U nion. There, the excesses of the Soviet regime were often interpreted in terms of Oriental despotism. ${ }^{77}$ This

70 A s D avid Chandler comments, 'Today's human rights advocates tend to portray every "ethical" intervention against selected pariah states as on a par with the Allied war effort against $\mathrm{N}$ azi Germany, the template for a moralised view of conflict. This ethical connection is mythologised through the human rights teleology that connects "ethical foreign policy" to the Genocide Convention of 1948 and the 1949 Geneva Conventions, which "were intended to establish a fire break between civilization and barbarism".' From Kosovo to Kabul: Human Rights and International Intervention (L ondon: Pluto, 2002), p. 77, quoting R oy G utman and D avid R ieff. Specialist scholarship is more attentive to the continuities between colonial genocides and the Holocaust. See, for example, M ahmood M amdani, When Victims Become Killers: Colonialism, Nativism, and the Genocide in Rwanda (Princeton, NJ: Princeton U niversity Press, 2001). Other scholars mention colonial genocides in passing but marginalise them in practice. See, for example, A ndrew Bell-F ialkoff, Ethnic Cleansing (N ew Y ork: St. M artin's, 1999).

71 Zygmunt Baumann, Modernity and the Holocaust (Cambridge: Polity, 2002).

$72 \mathrm{H}$ ans J oas, War and Modernity (Cambridge: Polity, 2003), p. 1.

73 L ewis and Wigen, Myth of Continents, p. 68.

74 David Blackbourn and Geoff Eley, The Peculiarities of German History: Bourgeois Society and Politics in Nineteenth Century Germany (N ew Y ork: Oxford U niversity Press, 1984).

75 L ewis and Wigen, Myth of Continents, p. 59.

76 Quoted in John Vinocur, 'F or the Germans, the war's ambiguities persist', International Herald Tribune, 7 J une, 2004, p. 1.

77 Patrick Thaddeus J ackson, Civilizing the Enemy: Postwar German Reconstruction and the Invention of the West (A nn A rbor, M I: U niversity of M ichigan Press, forthcoming 2006). See also K arl Wittfogel, Oriental Despotism: A Comparative Study of Total Power (N ew Y ork: Vintage, 1981 [1957]). 
reinforced the association of communism, a modern European ideology of progress, with the East. But as John G ray comments, 'Soviet Communism and $\mathrm{N}$ azism were each animated by ambitions that derive from the Enlightenment'. ${ }^{78} \mathrm{To}$ acknowledge this obvious fact is to contradict historical geographies that locate global progress and emancipation in the West and its ideas. When mass slaughter takes place in locales seemingly more removed from the W est, as in A frica, it is also attributed to non-Western factors such as the absence of modern political, economic and social arrangements, as in discourses of quasi- and failed states and of 'underdevelopment as dangerous', or to the peculiarities of local ethnic identities, as in the 'new barbarism' thesis. ${ }^{79}$ Similarly, M ary K aldor in part attributes 'new wars', located in the global South or in 'ambiguous' border zones like the Balkans, to the absence of 'cosmopolitan political consciousness'.80 The hierarchical relation between the W est and the rest is explicit: 'Cosmopolitanism tends to be more widespread in the West and less widespread in the East and the South. N evertheless, throughout the world, in remote towns and villages, both sorts of people are to be found'.81 Europe and the West show to the rest of the world its cosmopolitan and peaceful future. $\mathrm{M}$ oreover, to the $\mathrm{W}$ est is assigned the leading role in making that future real, through force if necessary. There are striking parallels between analyses couched in these terms and accounts of colonial war which, as Gottmann observed in 1943, is 'by its very nature, fought between adversaries of strikingly different levels of civilization'. ${ }^{82}$ M eanwhile, histories of cosmopolitanism in non-Western sites are forgotten. 83

As with the Cuban M issile Crisis and World War II, Eurocentrism generates substantial difficulties for understanding genocide and mass slaughter. Liberals seek to erect effective international legal and political structures for the prevention and eradication of mass slaughter. Such a task requires what we might term a natural history of genocide, that is, an account of the development and evolution of the modalities and practices of mass slaughter. ${ }^{84}$ Such a history is impossible if we begin from the kind of Eurocentric assumptions that mark liberal understandings of genocide. As Bauman demonstrates, "every "ingredient" of the Holocaust ... was normal ... in the sense of being fully in keeping with everything we know about our civilisation, its guiding spirit, its priorities, its immanent vision of the world - and of the proper ways to pursue human happiness together with a perfect society'. ${ }^{85}$ A nother site of mass slaughter central to any serious attempt to construct such a

78 J ohn Gray, Al Qaeda and What It Means To Be Modern (London: Faber and F aber, 2003), p. 14.

79 See, for example, R obert Jackson, Quasi-States: Sovereignty, International Relations and the Third World (Cambridge: Cambridge U niversity Press, 1993); cf. Siba N 'Zatioula G rovogui, Sovereigns, Quasi-Sovereigns: Race and Self-Determination in International Law (M inneapolis, M N : U niversity of M innesota Press, 1996). On 'underdevelopment as dangerous' and 'new barbarism', see M ark Duffield, Global Governance and the New Wars: The Merging of Development and Security (L ondon: Zed Books, 2001), ch. 5.

$80 \mathrm{~K}$ aldor, Old Wars and New Wars, pp. 76-89. On the Balkans, see L ewis and Wigen, Myth of Continents, pp. 67-8.

81 Kaldor, Old Wars and New Wars, p. 89

82 G ottmann, 'Bugeaud, G alliéni, L yautey', pp. 234-5. Cf. R oxanne D oty, Imperial Encounters (M inneapolis, M N : U niversity of M innesota Press, 1996).

83 See, for example, Sami Zubaida, 'Cosmopolitanism in the M iddle East', in R oel M eijer (ed.), Cosmopolitanism, Identity and Authenticity in the Middle East (London: Curzon, 1999), pp. 15-34.

${ }^{84}$ Compare M amdani, When Victims Become Killers, p. 7.

85 Baumann, Modernity and the Holocaust, p. 8. 
natural history lies in Europe's colonies. For Hannah A rendt, European colonial genocide is the progenitor for the Holocaust. 86

$M$ ass slaughter and loss of life amongst the 'natives' was a normal and routine feature of European expansion into and rule over the non-European world. As Sven Lindqvist observes, 'the Holocaust was unique- in Europe. But the history of Western expansion in other parts of the world shows many examples of total extermination of whole peoples.' ${ }^{87}$ So normal was mass death in the colonies that even as the A llies were fighting the 'good war', 3.5-3.8 million Bengalis - more than 'half a H olocaust' - died in 1943-44 as a predictable result of war-time exigencies and the grain market in British India. ${ }^{88}$ D espite urgent requests from B ritish officials in India, London refused to reallocate shipping space from military purposes. 'C hurchill expressed serious objection to the use of such a huge volume of transport for grain supply at the cost of military supply to India and civil supply to England'. ${ }^{89}$ The Viceroy of I ndia, L ord W avell, observed bitterly towards the end of the war that there was a 'very different attitude towards feeding a starving population when the population is in Europe'. 90 This was not the first time that large numbers of Indians had died as a direct result of British policies designed to produce a particular vision of the good life and the perfect society, organised around property rights, markets and free trade. ${ }^{91}$ The Irish too suffered from decisions made in London and the workings of liberal institutions. ${ }^{92}$ In the colonies, near and far, it was impossible to forget that the West was murderous. Questioning Eurocentric historical geographies - through recovery of these and other moments in the natural history of genocide and mass death - puts in serious doubt liberal and critical understandings of World War II as a good war and of the West as a force for good in world politics.

To sum up, then, security studies - across a range of prominent positions in the field - rests on and reproduces a variety of E urocentric assumptions. A s in Makers of Modern Strategy, a W estern political perspective is taken for granted. In analysis of key events, as in the Cuban M issile Crisis, agency is assumed to reside in the great powers. Eurocentric imagined geographies and histories, such as those through which the Second W orld War is known, provide the very foundation of security studies. In and through this mutually reinforcing set of claims, assertions, and presuppositions the oft-murderous West fashions itself as the ethical actor in world politics.

If security studies as presently constituted is overwhelmingly Eurocentric, why is this a problem? F irst, Eurocentrism in security studies produces basic difficulties in understanding the course and nature of events, that is, in empirical analyses of

86 Hannah A rendt, The Origins of Totalitarianism (San D iego, CA: H arcourt, 1985), esp. ch. 7; See also A imé Césaire, Discourse on Colonialism (N ew Y ork: N ew Y ork U niversity Press, 2000).

87 Sven Lindqvist, 'Exterminate All the Brutes' (London: Granta Books, 1996), p. 158. See also A dam Hochschild, King Leopold's Ghost: A Story of Greed, Terror and Heroism in Colonial Africa (N ew Y ork: Houghton M ifflin, 1998); Ward Churchill, A Little Matter of Genocide: Holocaust and Denial in the Americas 1492 to the Present (San Francisco, CA: City Lights, 1998); M ike Davis, Late Victorian Holocausts: El Nino Famines and the Making of the Third World (London: Verso, 2001).

88 Paul Greenough, Prosperity and Misery in Modern Bengal (Oxford: Oxford U niversity Press, 1982), p. 309.

89 Johannes Voigt, India in the Second World War (N ew D elhi: A rnold-H einemann, 1987), p. 207.

90 Penderel M oon (ed.), Wavell: The Viceroy's Journal (London: Oxford U niversity Press, 1973), p. 123. Wavell was referring to ample food supplies sent to $\mathrm{H}$ olland in early 1945.

91 Davis, Late Victorian Holocausts, esp. ch. 10.

92 James Donnelly, J r., The Great Irish Potato Famine (Stroud: Sutton Publishing, 2003). 
security relations. Whether we wish to understand crisis decision-making or the causes of genocide, adopting a Eurocentric set of assumptions - about agency, objectivity, and morality - gets in the way and hinders our efforts. Second, Eurocentrism in security studies also means that analysis winds up expressing a takenfor-granted politics that sides with the rulers, with the powerful, with the imperialists, and not with the downtrodden, the weak, the colonised, or the post-colonised. F or many scholars and analysts, whose concern it is to shore up and defend the interests of the powerful, this may not be an issue. F or others, however, the concern may be to support and defend the weak. Whatever the knowledge interests of individuals, we can and should be self-conscious of our presuppositions, something precluded by failing to recognise the political implications of our categories. This means there is both a social science problem and a political problem. We discuss these intimately interconnected problems in more detail in the next two sections.

\section{Security studies and the significance of the weak}

Barry Buzan and R ichard Little observe that '[a]t first sight, it might appear that there is nothing untoward about the familiar Eurocentric account of how the contemporary international system emerged. It seems to be almost self-evidently true that Europeans created the first global international system by bringing all parts of humankind into regular economic and strategic contact with each other.' 93 D espite our concerns regarding Eurocentrism, it is not surprising that Western, or A ngloA merican, security studies is by and for Western powers. Equally, there would not have been a Cuban M issile Crisis at all were it not for the worldwide rivalry of the superpowers; in this sense they were the key agents. While there were a variety of conflicts in and around World War II, at its core was a titanic struggle between the great powers, a struggle that left the U S in a position to dominate the postwar order. A nd for all its crimes and misdemeanours, errors and oversights, perhaps the W est is the best hope for a fair, just and peaceful world through its promotion of international institutions, rules, and humanitarian norms. Whether or not one agrees with this last, liberal interpretation of the West and its role in world politics, that the claim is made is unsurprising. A s any classical realist would observe, the powerful always prefer to think well of themselves. ${ }^{94}$

Taken together, these observations seem to support W altz's view that theories of international politics are of necessity primarily concerned with great powers. Given that for the past several centuries those powers have been overwhelmingly located in the West, analyses of world politics, and therefore security studies, are rightly Eurocentric. That is just the way the world is. 'It would be as ridiculous to construct a theory of international politics based on M alaysia and Costa Rica as it would be to construct an economic theory of oligopolistic competition based on the minor firms in a sector of an economy.' 95

93 Buzan and Little, International Systems in World History, p. 20.

${ }^{94}$ E. H. Carr comments: 'British writers of the past half-century have been particularly eloquent supporters of the theory that the maintenance of British supremacy is the performance of a duty to mankind'. The Twenty Years' Crisis, p. 76.

95 Waltz, Theory of International Politics, p. 72. Cf. Tickner, 'Seeing IR Differently', p. 301. 
W altz is updating in the language of neoclassical economics a truism of realpolitik, first and best expressed almost two and half thousand years ago by the A thenian general Thucydides: 'the strong do what they have the power to do and the weak accept what they have to accept'. ${ }^{96}$ Taken from the dialogue between the A thenian ambassadors and the Melian magistrates and oligarchs, this injunction is often presented in realist accounts as a description of the essential character of international politics. ${ }^{97} \mathrm{O}$ ccurring at the height of a ruinous war between the great powers of the day, the dialogue seems to us to highlight the fragility and complexity of power rather than its simple efficacy. ${ }^{98} \mathrm{~A}$ ccording to $\mathrm{D}$ onald $\mathrm{K}$ agan, the statement was part of a strategic ploy to 'convince the M elians to surrender without fighting'. I ndeed, the A thenians ' may have hoped to achieve this more readily by menace than by any other device'. ${ }^{99}$ Why, if the A thenians were so powerful, and the M elians so weak, was it necessary to resort to such ploys? The dialogue occurred during the second A thenian attempt to subdue $M$ elos in the Peloponnesian War. The first expedition was limited to laying waste M elian farmland because 'the capture of M elos was a far more difficult and expensive task and was not worth the strain on A thenian resources' at the time. 100 In the second expedition, M elos only capitulated after a protracted siege, involving successful $M$ elian sallies into the $A$ thenian lines, requiring further $A$ thenian reinforcements and only brought to a conclusion through treachery inside the city. ${ }^{101}$

Placed in its strategic context, the Melian dialogue takes on rather different meanings than those commonly attributed to it. As D aniel Garst comments, the second $\mathrm{A}$ thenian expedition to $\mathrm{M}$ elos highlighted 'a new and urgent anxiety about their control over their allies and empire.'102 The M elians, like many another small power then and since, proved a hard nut to crack, requiring precious resources in men, material and treasure. Exercising agency, they decided not to 'accept what they had to accept'. A thenian power, in common with many other great powers, was imperial in nature and required the effective organisation of tributary allies who submitted to the extent necessary and resisted where possible. In the M elian dialogue the A thenians remark that they fear their own subject peoples the most: ' $O$ ne is not so much frightened of being conquered by a power which rules over others as Sparta does... as of what would happen if a ruling power is attacked and defeated by its own subjects. '103 M elian brigandage was disrupting A thens' shipping and communications with its allies, while its independence was threatening to A thens' control over other cities. The subjection of M elos was intended to maintain A thenian prestige, an indication of the continuous and demanding nature of producing and maintaining imperial power.

In our view, the M elian dialogue reveals the mutually constitutive nature of world politics, the numerous and diverse ways in which the weak and the strong are bound

96 Thucydides, History of the Peloponnesian War (London: Penguin, 1972), p. 402.

97 See, for example, R obert K eohane, 'Theory of World Politics: Structural R ealism and Beyond', in K eohane (ed.), Neorealism and Its Critics (N ew Y ork: Columbia, 1986), pp. 158-203.

98 See, for example, Richard N ed Lebow, The Tragic Vision of Politics (Cambridge: Cambridge U niversity Press, 2003).

99 D onald K agan, The Peace of Nicias and the Sicilian Expedition (I thaca, NY : Cornell U niversity Press, 1981), p. 150.

100 D onald Kagan, The Archidamian War (Ithaca, NY : Cornell U niversity Press, 1974), p. 198.

101 K agan, Peace of Nicias, pp. 148-53; Thucydides, History, pp. 407-8.

102 D aniel G arst, 'Thucydides and N eorealism,' International Studies Quarterly, 33:1 (1989), p. 15.

103 Thucydides, History, p. 402. 
up together. The A thenian expeditions to M elos also draw attention to the many ways in which the resistance of the weak profoundly shapes events and outcomes. Like conventional interpretations of the M elian dialogue, Eurocentric accounts of great-power competition tend to take the weak - the 'natives', the colonies, the periphery, the Third World, the global South - more or less for granted. They do so in the specific sense that agency, rationality, power and morality, as well as the fundamental dynamics of world order, are assumed to reside in the global North. A Iternatively, these various others are assumed to be just like us, only weaker. This generates a different problem, inasmuch as it denies them their own history, their difference. ${ }^{104} \mathrm{~F}$ or us, in contrast to both of these perspectives, the M elian dialogue and the course and character of the Peloponnesian War draw attention to the dependence of A thens on its periphery, just as Sparta needed its helots and their labour. A s centres of power, what A thens and Sparta were depended crucially on an ongoing set of relations with their peripheries. The terms 'A thens' and 'Sparta', seemingly identifying discrete and concrete entities, too easily occlude this complex network of power relations and the processes through which they were maintained, or not.

What is true of A thens and Sparta is generally true of modern great powers; they were embedded in and dependent upon imperial relations of diverse kind. There is now a large and sophisticated historical and sociological literature tracing the mutual constitution of metropole and colony in the era of European imperialism. The key claim is that metropole and colony cannot be understood one without the other, they comprise a 'single analytic field'. ${ }^{105}$ That is, 'what we now call Europe, A frica, the A mericas and A sia were constructed together in the midst of a relationship, at once economic and cultural, military and political'.106 Eurocentrism in International Relations, the view that Europe is separate and self-producing, renders invisible this mutual constitution of core and periphery characteristic of great powers. ${ }^{107}$

Once vision is shifted from a fixation on the politics and policies of great powers to the ebb and flow of the social relations through which great powers - their societies, economies, cultures and armed forces - are constituted, reproduced and transformed, the imperial and the non-European world more generally take on equivalent importance. Throughout the era of European great-power politics, the source of many of security studies' archetypal categories, European politics and society were complexly interpenetrated with an imperial periphery. To cite one fact of a type central to any realist account of world politics, for much of its existence as a great power, Britain's leading strategic reserve was the Indian army. ${ }^{108}$

What was true of European economic and military power was also true of the constitution of European identities, which required an imaginary non-W estern

104 Inayatullah and Blaney, International Relations and the Problem of Difference.

105 F rederick Cooper and A nn L aura Stoler, 'Between M etropole and Colony: R ethinking a R esearch A genda', in Cooper and Stoler (eds.), Tensions of Empire: Colonial Cultures in a Bourgeois World (Berkeley, CA: U niversity of California Press, 1997), p. 4.

106 R ichard D rayton, 'The Collaboration of L abour: Slaves, Empires and G lobalizations in the A tlantic World, c. 1600-1860', in A. G. Hopkins (ed.), Globalization in World History (London: Pimlico, 2002), p. 103.

107 Tarak Barkawi and M ark Laffey, 'R etrieving the Imperial: Empire and International R elations', Millennium, 31:1 (2002), pp. 109-27.

108 Black, War and the World, p. 178. 
'other'. 109 The W est is defined through a series of contrasts regarding rationality, progress, and development in which the non-W est is generally found lacking. To take an example from the initial period of European expansion, W estern thinkers used the notion of the 'state of nature' to distinguish between their civilisation and those they encountered in the W estern Hemisphere after 1492. The 'state of nature' was itself a Eurocentric interpretation of these peoples which located civilisation and law in E urope even as E urope set about destroying these peoples and their civilisations. This metaphor, a core notion in Western political thought, only became possible as a result of Europe's imperial encounter with aboriginal peoples.110 A the same time, it enabled and legitimated European dispossession and appropriation of land, resources and populations. In this way, the 'state of nature' played its role in producing a world sharply divided between W estern have-lots and non-W estern have-nots. This idea has continuing significance in political theory and in discussions of contemporary security issues such as failed states and new wars, discussions which reproduce Eurocentric understandings of world politics. ${ }^{111}$ Contemporary violence in A frica is often explained in terms of a lack of those institutions and attributes associated with European modernity, such as sovereignty, rather than as a consequence of long histories of colonial and postcolonial interaction with the W est.

Part of the significance of the postcolonial rupture signalled in the attack on the W orld Trade Center and the Pentagon on 11 September 2001 is that it forces us to recover these processes of mutual constitution and their significance for how we make sense of security relations and world politics more generally. F or many, the War on Terror is a clash between the West and the Islamic world. A I-Q aeda, bin Laden and his allies are conceived as 'Islamic fundamentalists' with a passionate hatred of everything Western. The problem with this way of framing the conflict is that it ignores the long history of interconnection and mutual constitution out of which bin Laden's ideas and organisation were produced. Currents of Western, A rab and Islamic cultures and histories, modern technologies and communications, and the policies of various regimes and great powers combined to form crystallisations, amongst them bin Laden's and A I-Q aeda's particular way of being modern. Attempting to disaggregate these phenomena and squeeze them into boxes marked 'Islam' and 'the W est' will not aid understanding of the dynamics of the War on Terror. M ore importantly, policies derived from such binary understandings may create the very conditions that crystallise future bin Ladens and A I-Q aedas.

Bin Laden's 'I slamic fundamentalism' and the Al-Q aeda organisation are in fact modern, hybrid creations of Islam's encounter with the W est.112 Two of the key figures behind contemporary Islamic thinking, Sayyid Qutb and his brother M uhammad, who was bin Laden's teacher at K ing A bdul A ziz U niversity in Saudi A rabia, viewed the W est as suffering from a 'great spiritual famine'. ${ }^{113} \mathrm{M}$ uch of their thought is a reaction against $W$ estern modernity and an attempt to outline a new,

109 Edward Said, Orientalism (N ew Y ork: Pantheon, 1978); cf. F ernando Coronil, The Magical State (Chicago: U niversity of Chicago Press, 1997), pp. 13-15.

110 Beate Jahn, The Cultural Construction of International Relations: The Invention of the State of Nature (L ondon: Palgrave M acmillan, 2000).

111 See, for example, Stathis N. K alyvas, " "N ew" and "Old" Wars: A Valid Distinction?', World Politics, 54:1 (2001), pp. 99-118.

112 Oliver R oy, Globalised Islam (L ondon: H urst, 2004).

113 Gray, Al-Qaeda, p. 77. 
Islamic modernity, for they did not want the same fate to befall their societies. The W est was not only an initial impetus to their ideology, they also utilised a variety of quintessentially Western ideas. Qutb was influenced in particular by M arxismLeninism, taking the concept of a revolutionary vanguard and the idea that the world could be remade through an act of will, both important intellectual bases of A I-Q aeda. $\mathrm{H}$ is notion that I slam could serve as a universal ideology of emancipation in modern conditions is a distinctive combination of Islamic and Enlightenment thinking. 114

The A I-Q aeda organisation itself is even more obviously of the modern world, rather than simply a product of 'I slam'. It is a contemporary, global and networked enterprise, with a flattened hierarchy and cellular structure. It is comfortable with computer technology and modern communications. A I-Q aeda also has direct debts to US foreign policy. Bin Laden's central role and his organisation developed out of the U S supported resistance to the Soviet-backed regime in $\mathrm{K}$ abul. ${ }^{115}$ It is through diverse forms of interaction between peoples and places around the world that 'Islamic fundamentalism' and AI-Q aeda came into existence; they were mutually constituted out of hierarchical relations of interconnection.

Our point here is not to provide a full account of A I-Q aeda but rather to highlight in an initial way the kinds of research questions as well as the larger research agenda opened up for security studies by a focus on the mutual constitution of the strong and the weak, amid relations of domination and subordination. F or security studies after Eurocentrism, the history and politics of warfare and struggle between what we now call the global North and the global South must become a major focus for inquiry. Especially in the age of the War on Terror, with its avowedly colonial projects and rhetorics in Iraq, A fghanistan and elsewhere, there needs to be greater attention to the histories and processes of imperial subjugation and the resistance it has so regularly generated. The imperial character of great powers - in all its dimensions directs inquiry to the constitutive relationship between core and periphery, and in so doing to a reconceptualisation of what a great power is in security studies. This involves explicit recognition and analysis of the many ways in which political, economic and military power is produced out of relations between the strong and the weak, relations that are as necessary as they are contested. The insight of mutual constitution is no less applicable to the character and nature of the weak themselves, as for A I-Q aeda. They too are formed out of their relations with the powerful.

R ecognition of the mutually constitutive character of world politics has implications for the nature of explanation. There is a strong tendency across the social sciences to divide up the world into a series of discrete spaces and locate the causes of events and processes in one site or another. Security studies, as we have shown, privileges the agency of great powers, while area studies often emphasises local factors. ${ }^{116}$ I $n$ contrast, we wish to highlight the significance of the relations between spaces and populations, and their role in driving events and processes, as well as in constituting seemingly discrete spaces and entities in the first place. M ethodologically, this means that it cannot be assumed in advance that events and their

\footnotetext{
114 M amdani, Good Muslim, Bad Muslim, pp. 56-60.

115 Gabriel Kolko, Another Century of War? (N ew Y ork: The N ew Press, 2002).

116 Compare M asao M iyoshi and H. D. Harootunian (eds.), Learning Places: The Afterlives of Area Studies (D urham, N C: D uke U niversity Press, 2002).
} 
explanation are always to be found in the same place, even in the case of large and powerful states.117 'Contrapuntal studies' that analyse events, developments and processes in core and periphery together, offer one example of what is required.118

F or purposes of critiquing security studies, we have deployed a set of categories, such as N orth-South and strong-weak, that we are not fully able to develop here.119 A key feature of these alternative categories is that they are relational in nature; you cannot have the $\mathrm{N}$ orth without the South. R elational processes connect the world. In so doing, they remake and interconnect spaces; they have a geographic expression. For example, as Sidney M intz shows, Eastern techniques of sugar production, A frican slave labour, English capital, and Caribbean land together remade Europe and the $\mathrm{N}$ ew World.120 The global N orth and the global South were co-produced through processes of imperial expansion and neocolonial domination. Relational thinking provides inherent defences against Eurocentrism because it begins with the assumption that the social world is composed of relations rather than separate objects, like great powers or 'the W est'. Explanation is then centred on the relations rather than apparently discrete entities. To be sure, there is no direct correlation between analytic categories like strong and weak and spatial categories like $\mathrm{N}$ orth and South. N onetheless, relations between the strong and the weak have geographic consequences, some of which are captured by the categories of $\mathrm{N}$ orth and South. The spatial categories of security studies, such as the Third W orld, territorial states, great powers, failed states, and now civilisations, are typically conceived in non-relational terms, as separate and discrete. A security studies conceived in these terms is inadequate. The social context of armed conflict is a world of relational processes, a world which must be studied in relational terms.

\section{Security studies and the right to bear arms}

$M$ aking sense of security relations requires putting the weak and the strong in a common analytic frame. But more is at stake in our critique of Eurocentrism in security studies than the adequacy of social scientific analyses. In conventional form, security studies takes the perspective of the powerful, of those who have colonised, dominated and competed over the world. There is a politics to security studies and it is the politics of the strong. As E. H. Carr remarked in 1977, '[t]he study of international relations in English speaking countries is simply a study of the best way to run the world from positions of strength. The study of international relations in A frican and Asian U niversities, if it ever got going, would be a study of the exploitation of the weaker by the stronger.'121 These considerations take on

117 See, for example, Thomas Bender (ed.), Rethinking American History in a Global Age (Berkeley, CA : U niversity of California Press, 2002).

118 Edward Said, Culture and Imperialism (N ew Y ork: K nopf, 1993).

119 F or example, with Sherry Ortner we recognize that the categories of weak and strong are multiple, not unitary: 'R esistance and the Problem of Ethnographic R efusal', Comparative Studies in Society and History, 37:1 (1995), p. 175.

120 Sidney M intz, Sweetness and Power: The Place of Sugar in Modern History (London: Penguin, 1985).

121 Quoted in J onathan H aslem, The Vices of Integrity: E. H. Carr 1892-1982 (London: Verso, 1999), pp. 252-3. 
additional significance when security studies informs a strategic studies, the rational use of force in pursuit of objectives.

It is a common observation that security studies is overwhelmingly done in and for the most powerful states in the international system. A s a problem-solving discourse, conventional security studies is produced out of an extensive and well-developed set of institutions and personnel located at the intersection of the state and the academy. ${ }^{122} \mathrm{~F}$ rom the initial systemisation of general staffs in the nineteenth century to the contemporary galaxy of university departments, think tanks, and security and defence policy planning staffs, there has emerged an extensive and sophisticated, albeit Eurocentric, body of knowledge.

That said, much contemporary writing in the field of security studies is explicitly and self-consciously critical of the policies of W estern states. H ow can we then claim that security studies as a whole exhibits a E urocentric politics? The politics of critical and human security approaches revolve around the concept of emancipation, an idea derived from the European Enlightenments. In this literature, the agent of emancipation is almost invariably the West, whether in the form of Western-dominated international institutions, a Western-led global civil society, or in the 'ethical foreign policies' of leading W estern powers. ${ }^{123}$ C ritics of W estern states find themselves in the position of relying on Western armed forces for humanitarian interventions, especially when actual fighting is required, as Paul $\mathrm{H}$ irst demonstrates in his incisive critique of M ary K aldor's New and Old Wars. ${ }^{124} \mathrm{E}$ ven when the concrete agents of emancipation are not themselves Westerners, they are conceived as the bearers of W estern ideas, whether concerning economy, politics or culture.

In our critique of the politics of conventional security studies, what we wish to emphasise is the everywhere taken-for-granted assumption that it is the powerful, most prominently the West, other great powers and their clients, who have the right to bear arms. A strong distinction is drawn in international law and state practice regarding war between the conventional armed forces of sovereign states and the kind of armed resistance the weak are generally able to mount. Such resistance often takes the form of insurgency, ambush, raids, banditry, hostage-taking, assassination, bombings, and other tactics which reflect the exigencies of asymmetric warfare. Violent resistance, however justified and for whatever purpose, is often ugly. Unsurprisingly, this violence, often rational and effective for the weaker party, is systematically delegitimated by the W est. This is evident in the terms used publicly to identify those who resort to violent weapons of the weak. For example, four years into the $\mathrm{M}$ alayan $\mathrm{E}$ mergency, the British dropped the term 'bandit' for the insurgents and adopted 'Communist Terrorist'. ${ }^{125}$ In the wake of 9/11, the military historian Sir J ohn K eegan drew a distinction between W estern and O riental traditions of warfare: 'W esterners fight face to face, in stand-up battle ... [observing] rules of honour. Orientals ... shrink from pitched battle ... preferring ambush, surprise, treachery

122 In a U S context, see, for example, Bruce Cumings, 'Boundary Displacement: the State, the Foundations, and A rea Studies during the Cold War', in M iyoshi and H arootunian (eds.), Learning Places, pp. 261-302; Ellen Herman, The Romance of American Pyschology: Political Culture in the Age of Experts (Berkeley, CA: U niversity of California, 1995).

123 See, for example, Chandler, From Kosovo to Kabul, pp. 218-219.

124 Paul Hirst, War and Power in the 21 st Century (Cambridge: Polity, 2001), pp. 86-8.

125 Susan Carruthers, Winning Hearts and Minds: British Governments, the Media and Colonial Counter-Insurgency 1940-1960 (L ondon: L eicester U niversity Press, 1995), pp. 84-5. 
and deceit.' 126 President G.W. Bush referred to the tactics used by the militias opposing the invasion of I raq in the Spring of 2003 as 'cowardly' and 'terrorist'. ${ }^{127}$ A s Victor Davis Hanson observes, 'we in the West call the few casualties we suffer from terrorism and surprise "cowardly", the frightful losses we inflict through open and direct assault "fair" '.128

In armed conflict between the global $\mathrm{N}$ orth and the global South, W estern use of force is legitimated in terms of a civilising mission of one kind or another. Whether 'white man's burden', humanitarian intervention in the 1990s, or the post-9/11 invasions of A fghanistan and Iraq, the assumption is that it is the right of the West to bear arms to liberate the 'natives'. This is and has always been the primary justification of imperialism in all its forms; it is about civilising the barbarians. ${ }^{129}$ Viewed from the global South, the results of the civilising mission over the last several centuries are at best mixed. Setting aside the mass die-offs of the initial stages of E uropean expansion, nineteenth-century imperialism worked to divide humanity. As $M$ ike $D$ avis observes:

[W ]hat we today call the 'third world' (a Cold War term) is the outgrowth of income and wealth inequalities - the famous 'development gap' - that were shaped most decisively in the last quarter of the nineteenth century, when the great non-E uropean peasantries were initially integrated into the world economy ... By the end of Victoria's reign .... the inequality of nations was as profound as the inequality of classes. Humanity had been irrevocably divided. ${ }^{130}$

In such conditions, and in the world of profound inequalities they produced, armed and other resistance is only to be expected. F or us, the 'natives' have a right to bear arms for purposes of their own liberatory projects, even those we profoundly disagree with.

The politics of a non-E urocentric security studies, a M elian security studies as it were, necessarily stands on the other side of this divide, with the weak against the strong, with the many against the few. To advise the weak that they should not take up arms but instead await liberation at the hands of the West is wishful thinking given the historical record of the West in this regard. M ost recently, the W est has delivered neoliberalism and the War on Terror to the global South rather than emancipation. In contrast to those to day who place their hopes upon W estern use of force under the auspices of the UN or the international community, generations of Southern resistance movements instead put faith in their own use of force. F or F rantz $\mathrm{F}$ anon, $\mathrm{M}$ ao Zedong and others the use of force by the weak themselves was an inherent and useful dimension of liberatory projects. Force indeed has had some significant successes in the global South, as in China, Indonesia, Algeria, Cuba, $\mathrm{V}$ ietnam and $\mathrm{N}$ icaragua.

To be sure, the ultimate achievements of these liberation struggles were contestable, ambiguous, and more or less overturned, in no small measure because of the hostility of the international environment into which they emerged. Our point here is

126 Quoted in Gregory, Colonial Present, p. 58.

127 See, for example, 'Operation Iraqi F reedom', President's R adio A ddress, 5 A pril 2003, 〈http://www.whitehousegov/news/releases/2003/04/20030405.html〉, accessed 7 J anuary 2005.

128 Victor Davis Hanson, Carnage and Culture: Landmark Battles in the Rise of Western Power (N ew York: A nchor, 2002), p. 97.

129 M ark Salter, Barbarians and Civilization in International Relations (L ondon: Pluto, 2002).

130 D avis, Late Victorian Holocausts, pp. 15-16, footnote omitted. 
not to make definitive normative judgements concerning the relative merits of these efforts. Rather, the purpose is to draw out the political implications of our critique of Eurocentrism in security studies. There are legions of scholars in the AngloA merican academy who devote themselves to a security studies for the strong, one which informs the security and defence policies - including those involving the direct use of force - of the leading powers and the putative 'international community'. This is considered a normal, legitimate, and even patriotic career choice.

We consider it equally legitimate for Western scholars and others to work in M elian security studies, including its strategic and problem-solving dimensions. In this way, the critique of Eurocentrism in security studies opens up space for scholars to analyse the strategic and security dilemmas confronting the weak and their use of force. If it is acceptable for scholars to work in and for the Pentagon, the $\mathrm{N}$ ational Security Council and the UK M inistry of D efence, should it not also be acceptable for scholars to advise the Palestinians, the Tamils, the Chechens, the Iraqi resistance and others in their armed struggles? Equally, a security studies for Third World or Southern states, of the kind initially mapped out by M ohammed A yoob, is also a legitimate arena for inquiry. ${ }^{131}$ The critique of Eurocentrism leads to greater pluralism in security studies for both the topics we study and the knowledge interests we serve.

\section{Conclusion}

The attacks of $9 / 11$ and the subsequent War on Terror prompt efforts to rethink security relations. We too have used $9 / 11$ as an incitement to discourse. F or a long time, security studies mostly relied on realism. In political theoretic terms, realism is a richer and more diverse tradition than its instantiation in the field of IR, one concerned with stripping power of its illusions. It is in this sense that the work of figures as diverse as $\mathrm{K}$ arl $\mathrm{M}$ arx, $\mathrm{M}$ ax $\mathrm{W}$ eber and $\mathrm{M}$ ichel $\mathrm{F}$ oucault can be characterised as realist. This article relies on such a sensibility to expose the Eurocentrism of security studies. Viewed in this light, conventional security studies sits at the intersection of power and knowledge. Whether in terms of the historical geographies that inform its empirical analyses, the taken-for-granted politics that structure its questions and theories, or the role of the state in shaping its research agendas, conventional security studies as a field of knowledge is a product of Western power. The knowledge produced out of such a field is inadequate even to its own clientele. It is even less adequate at addressing the security and strategic concerns of the weak, the vast majority of the people living on the planet. Security studies, and the policies it informs, have a lot to gain by waking up to the significance of the $M$ elians and their kin. We all have a lot to lose if it fails to do so. 